\title{
Administrative justice as a deterrent to the implementation of tasks within criminal proceedings
}

\section{Адміністративна юстиція як стримуючий чинник вирішення завдань у рамках кримінального судочинства}

Received: April 4, 2021

\begin{abstract}
The purpose of the article is to clarify the problems of the institution of administrative justice of Ukraine in the context of the implementation of tasks within criminal proceedings. Subject of research: The subject of the research is the shortcomings in the administrative justice of Ukraine that can create obstacles to achieving the objectives within criminal proceedings. Methodology: The methodological basis of the article are general and special methods of legal science, in particular: dialectical method, logical and semantic method, methods of analyses and synthesis, system and structural method, formal and legal method, method of generalization. Research results: The bases for administrative justice in Ukraine are characterized, its value and main shortcomings are determined. Practical implications: The problems of administrative justice, which are a deterrent to solving problems in criminal proceedings, are analyzed. Value / originality: The consequences of the considered legal incompatibilies are determined and the ways to overcome them are suggested.
\end{abstract}

Key words: administrative justice, administrative proceedings, criminal proceedings, administrative and criminal law, offenses.
Accepted: May 8, 2021

Written by:

Paryzkyi Ihor ${ }^{32}$

https://orcid.org/0000-0001-6835-5930

Matvieiev Serhii ${ }^{33}$

https://orcid.org/0000-0002-0037-004X

Bratel Serhii $^{34}$

https://orcid.org/0000-0001-6826-2582

Komirchyi Pavlo ${ }^{35}$

https://orcid.org/0000-0002-2794-6520

Zubko Artem $^{36}$

https://orcid.org/0000-0003-2025-0202

\begin{abstract}
Анотація
Метою статті $є$ з'ясування проблем інституту адміністративної юстиції України в контексті реалізації завдань в рамках кримінального судочинства. Предмет дослідження: Предметом дослідження $\epsilon$ проблеми інституту адміністративної юстиції України в контексті реалізації завдань в рамках кримінального судочинства. Методологія: Методологічною основою статті є загальні та спеціальні методи юридичної науки, зокрема: діалектичний метод, логіко-семантичний метод, методи аналізу та синтезу, системно-структурний метод, формально-правовий метод, метод узагальнення. Результати дослідження: охарактеризовано основи адміністративної юстиції в Україні, визначено іiі цінність та основні недоліки. Практичні наслідки: Проаналізовано проблеми адміністративної юстиції, які виступають стримуючими чинниками розв'язання завдань у рамках кримінального судочинства. Цінність / оригінальність: Визначено наслідки розглянутих правових неузгодженостей та запропоновано шляхи їх подолання.
\end{abstract}

Ключові слова: адміністративна юстиція, адміністративне судочинство, кримінальне судочинство, адміністративне та кримінальне право, правопорушення.

\footnotetext{
${ }^{32}$ Doctor of Economics, Candidate of Law, Professor of the Department of Marketing, Economics, Management and Administration, Vice-Rector for Strategic Development of the "National Academy of Management", Ukraine.

${ }^{33} \mathrm{PhD}$ in Law, Associate Professor, Dean of the Faculty of Law of the National Academy of Management, Ukraine.

${ }^{34} \mathrm{PhD}$ in Law, Associate Professor, Professor of the Police Law Department of the National Academy of Internal Affairs, Ukraine.

${ }^{35}$ Doctor of Law, Associate Professor, Professor of the Department of Public Management and Administration of the National Academy of Internal Affairs, Ukraine.

${ }^{36} \mathrm{Ph} . \mathrm{D}$. in Law, Post-Doctoral Student, Scientific Institute of Public Law, Kyiv, Ukraine.
} 


\section{Introduction}

The formation of an effective mechanism for the protection of rights in the rule of law implies the functioning of an effective judicial order for the protection of rights in public law relations. Today, such an order is linked to the functioning of administrative justice in Ukraine (Lahutina, Osadchyi, Zakalenko, Kozachuk, \& Bolshakova, 2019, p.).

The judicial system is designed to ensure justice, upholding the rights and freedoms of an individual and citizen, adhering to the balance of private and public interests (Shcherbaniuk 2013, p. 66). However, the correct qualification of illegal acts and the choice of the court authorized to consider a particular case are of great importance. This problem is especially acute with respect to administrative and criminal justice, because it is due to the ambiguous resolution of the question of whether a dispute or other legal issue belongs to a particular judicial system, which ultimately leads to the violation of human right to a fair trial within a reasonable time, or the improper qualification of the offense poses a threat to society because of the inability to prosecute for the offense. All this determines the relevance of this study.

Thus, the purpose of the article is to clarify the problems of the institution of administrative justice of Ukraine in the context of the implementation of tasks within criminal proceedings.

\section{Methodology}

Dialectical method contributed to the consideration and study of the problem in the unity of its social content and legal form, as well as to the analysis of the legal basis for administrative justice in Ukraine.

With the help of logical and semantic method the scientific basis for the research of the organization of administrative proceedings in Ukraine is defined. The problems of administrative justice, which are a deterrent to solving problems in criminal proceedings, were also defined with the help of this method.

The methods of analyses and synthesis were used to determine the inconsistencies that create opportunities to avoid or reduce liability in administrative law.

System and structural method allowed to identify the norms of the Criminal Code of Ukraine and the Code of Administrative Offences of Ukraine that may lead to the mischaracterization of administrative and criminal offences and definition of subject matter jurisdiction of cases.

Using formal and legal method the legal basis regulating the issue under consideration was examined.

The method of generalization was applied to formulate the relevant conclusions and propositions.

\section{Literature Review}

Svida (2008) paid attention in his work "Administrative Courts in Ukraine: Formation and Prospects for Development" not only to the study of the place and tasks of administrative courts in the mechanism of protection of human rights, freedoms and interests, but also presented the results of his research with relation to the place of administrative courts in the entire judicial system of Ukraine.

Smokevych (2009) examined the categories of jurisdiction of administrative courts, studied the content and general criteria for determining the jurisdiction of courts, criteria for establishing the court competence and special criteria for identifying disputes falling within administrative courts competence..

The work of Vynokurova (2011) is one of the most fundamental and comprehensive in the study of the place of administrative courts in the system of State bodies of Ukraine. The dissertation deals with such issues as the problems of determining the jurisdiction of administrative courts, the competence of administrative courts as judicial authorities and the principles of administrative justice.

Pypiak (2016) considered the functioning of the system of administrative courts in Ukraine, the areas for improving their activities and interaction with other public authorities. The author also analyzed the genesis of the formation and development of administrative justice, studied the activities of administrative courts in foreign countries and highlighted the positive experience of developed countries, which is proposed to implement in Ukraine.

The peculiarities of administrative justice in different countries were considered by a number of scholars. For example, Hood (2018) states that 


\section{AMAZONDA}

this type of jurisdiction is a cornstone of social justice. It is an effective way to bring the public officials to liability when the other measures failed. The author studies the experience of Wales on this issue and comes to the conclusion that there are still a lot of shortcomings in this sphere.

Monell (2016) considers the US model of administrative justice. He provides the definition of this concept, describes its models and gives the examples of their application.

Parker (1991) tried to contribute to the development of administrative justice in Namibia by conducting his research. He believes that this type of justice can ensure the good-faith behavior of public officials and make them to act in the manner prescribed by law.

Russell-Einhorn and Chlebny (2006) presented an analytical overview of the administrative justice system in the Republic of Macedonia. They also proposed the ways for its improvement through making relevant changes in different areas of social life.

\section{Results and Discussion}

In September 2006 Ukraine has adopted the Code of Administrative Procedure (Law No. 2747-IV, 2005) and thereby created the system of administrative justice, the task of which is to ensure the protection of the rights and interests of individuals and legal entities from violations on the part of government officials in the area of public relations, i.e. from any administrative offenses (Khavroniuk, 2015).

The value of administrative justice is indisputable given the specifics of public relations, which it regulates, as the participants of such legal relations, as a rule, have unequal opportunities; the challenges in protecting the interests of citizens and society in such relations is due to subordination of persons in these relations to the officials and bodies, which perform managerial functions and have support of a powerful administrative apparatus (Aleksandrova, 2009, p. 12). However, in order for administrative justice to fully perform its functions, it is necessary to avoid the shortcomings of administrative legislation and legal conflicts, which make it possible to influence the course of proving illegal actions and establishing due responsibility for offenses.

In this aspect, we see administrative justice as a deterrent to solving problems in criminal proceedings, through:

- the problem of determining the substantive jurisdiction, which is associated with the incorrect classification of offenses and the difficulty of distinguishing administrative offenses from other illegal acts;

- the problem of implementation of the principles of the efficiency of administrative proceedings, which in practice is expressed in violation of procedural deadlines, accompanied by closing the cases due to expiry of administrative penalty;

- closure of a criminal case due to the expiration of the statute of limitations that arises in the case (if the administrative offense acquires the characteristics of a criminal offense or crime).

Now let's consider the indicated problems in more detail.

The challenges in determining the subject matter jurisdiction is caused by the problem of distinguishing crimes from administrative offenses, which arises in dozens of cases. It is most often manifested when considering categories of cases related to encroachments on property, environment, economic and official activities, etc. (Table 1); due to insufficiently clear wording of the articles of the Special Part of the Criminal Code of Ukraine (Law No. 2341III, 2001) and Code of Administrative Offences (Law No. 80731-X-VR, 1984), when the dispositions of the relevant articles do not explicitly indicate the indicia of difference between offences and administrative offences, if they are formulated in terms of formally defined concepts, or evaluation terms, the content of which is not specified in criminal law or acts other branches of law (Brych, 2006). 
Table 1

Norms of codified acts that may lead to mischaracterization of administrative and criminal offences and determination of the subject-matter jurisdiction of cases. (prepared by the authors of the article)

\begin{tabular}{l} 
Rules of the Code of Administrative Offenses of \\
Ukraine \\
\hline Part 1, Article 41. Violation of requirements of \\
the legislation on work and about labor protection
\end{tabular}

Art. 152 Infringement of Intellectual Property Right Object Rights

Art. 921. Violation of the Law on the National Archives Fund and Archives Institutions

Article 173. Minor hooliganism

Art. 210 Violation of the law on conscription by persons liable for military service or conscripts Article 186. Unauthorized action Article 51. Petty theft of alien property Article 123. Violation of the rules for moving through level crossings;

Article 124. Violation of traffic rules, which caused damage to vehicles, cargo, roads, streets, level crossings, road structures or other property; Article 125. Other violations of traffic rules Article 126. Driving a vehicle by a person who does not have the relevant documents for the right to drive such a vehicle or has not presented them for the inspection

Article 52. Spoil and pollution of agricultural and other lands

Article 53-4. Illegal taking soil cover (blanket) of lands

Article 57. Violation of requirements for protection of subsoil

Article 58. Abuse of regulations and requirements of work for geological studying of subsoil Article 59. Abuse of regulations of protection of water resources

Article 175. Violation of the requirements of fire safety established by the legislation

Article 164. Violation of the legislation governing the implementation of operations with scrap metal

Article 1062. Illegal sowing and cultivation of sleeping poppy or hemp

Article 147. Violation of the rules of protection of communication lines and structures"

Article 187. Violation of the rules of administrative supervision

However, currently there are a number of inconsistencies that create opportunities to avoid or reduce liability in administrative law; in particular we can highlight the following:

- the problems in indicating the indicia of difference between crimes and
Rules of the Criminal Code of Ukraine

Article 172. Gross violation of labor law

Part 1, Article 176. Violation of copyright and allied rights

Part 1, Article 177. Violation of the rights to invention

Part 1, Article 298-1. Destruction, damage or concealment of documents or unique documents of the National Archive Fund

Part 1, Article 296. Hooliganism

Article 337. Avoidance of military registration or special assemblies

Article 356. Unauthorized action

Article 185. Theft

Part 1, Article 286. Violation of rules related to traffic or driving safety by drivers

Part 1, Article 286-1. Driving under the influence of alcohol, drugs or other substances

Part 1, Article 239. Contamination or deterioration of land

Part 1, Article 239-2. Misappropriation of lands of water resources on an especially large scale Part 1, Article 240. Violation of rules related to the protection of mineral resources

Part 1, Article 242. Violation of rules related to water protection, etc.

Part 1, Article 270. Violation of fire safety requirements established by law

Part 1, Article 213. Violation of procedures related to operations with scrap metal

Part 1, Article 310. Planting or cultivation of opium poppy or cannabis

Article 360. Willful endamagement of communication lines

Article 395. Violation of rules related to administrative supervision

administrative offences arise mainly when the elements of crimes and administrative offences are formulated in law by means of evaluative concepts, the content of which is not specified;

- the problem of delimitation of offenses, when the same act is provided in the 
Criminal Code as a crime and in the Code of Administrative Offenses, or another law establishing administrative liability - as an administrative offense. This occurs when the dispositions of the relevant articles of the Criminal Code of Ukraine and Code of Administrative Offences coincide textually or are identical in content. Thus, the combination of the same elements constitutes an administrative offence and forms the composition of the crime at the same time;

- the challenges in indicating the indicia of difference between crimes and administrative offences arise when there is a gap between the maximum size of the consequences provided in the article of the Code of Administrative Offenses (Law No. 80731-X-VR, 1984) as a sign of the offense and the minimum size of socially dangerous consequences provided in the article of the Criminal Code of Ukraine (Law No. 2341-III, 2001).

Another critical issue for administrative justice today is the implementation of the principles of efficiency of administrative proceedings, which in practice is expressed in violation of procedural deadlines. This, in turn, leads to the closure of cases of administrative offenses in connection with the expiration of the period of prosecution for the act. In this case, the proceedings cannot be initiated, and the initiated one is subject to closure on the basis of Par. 7, Part 1, Art. 247 of the Code of Administrative Offenses (Law No. 80731-X-VR, 1984).

The terms of imposition of administrative penalties in Ukraine are defined by Article 38 of the Code of Administrative Offenses (Law No. 80731-X-VR, 1984); they are: two months from the date of the commission of the offence, and in the case of a continuing offence two months from the date of its detection. If the case is under the jurisdiction of a court (judge), a penalty may be imposed no later than three months from the date of the commission of the offense, and in the case of a continuing offense no later than three months from the date of its detection.

Although, from a practical point of view, these terms are insufficient to make a decision on an administrative offense, which leads to the dangerous sense of impunity for violations (Banchuk, 2007), because the Code of Administrative Offenses clearly states that the expiry of the period for imposing administrative penalties is grounds for excluding proceedings in a case at any of the following stages: a) legal assessment of the collected materials; b) complete and comprehensive study of the case; c) establishing the objective truth in the case; d) making decisions (resolutions) and bringing them to the attention of the participants in the proceedings (Demskyi, 2008). Therefore, after the exclusion of the proceedings, it is impossible to take any measures aimed at bringing person to administrative responsibility.

If an administrative offense turns into a crime (an administrative offense acquires the features of a crime, or an administrative offense is committed for the second time), the person, who committed it, is subject to criminal prosecution. However, the proceedings, consideration of the case in the court of the first instance, consideration of the case in the court of higher instance, as well as cases of intentional delay may lead to the closure of the case due to the expiry of the period of limitation. This is due to the fact that the criminal justice system is somewhat cumbersome, internally contradictory, not always scientifically substantiated and overly complicated. The activities of its subjects are characterized by duplication of powers, lack of clear definition and delimitation of their competence, giving priority to the tasks that are actually secondary ones, the use of unnecessarily complicated formal procedures.

Unfortunately, the use of the "delay strategy" (when the consideration of the case is intentionally delayed by the defense through submitting all kinds of petitions provided by the law of criminal procedure (abuse of procedural rights) until expiry of the period of limitation) is quite common practice. Thus, under the influence of these circumstances, the court may release a person from criminal liability in connection with the expiration of the period of limitation with the closure of criminal proceedings both during the preparatory hearing and during the trial in general, guided by the provisions of Art. 49 of the Criminal Code of Ukraine.

The consequences of such a procedural decision are primarily a guarantee of ensuring the right of a person to timely pre-trial investigation and consideration of the case by the court within a reasonable time. At the same time, such closure cannot be considered as an instrument for the defence of a person because of its nonrehabilitative nature (Bilous, 2020). However, for a person who admits the guilt, closing the case under the statute of limitations is a kind of way to avoid criminal liability. 
We also consider it important that the closure of cases for various reasons mentioned above, makes it impossible to re-prosecute the perpetrators; thus, Art. 61 of the Constitution of Ukraine (Law No. 254k/96-VR, 1996) states that "for one and the same offence, no one shall be brought twice to legal liability of the same type". This, in turn, can lead to the sense of impunity and provoke other offenses that can have a significant level of public danger and threaten not only the individual but also the State as a whole.

Therefore, the inconsistency of administrative and criminal law in Ukraine, as well as certain problems of administrative justice act as a deterrent to solving problems in criminal proceedings and require appropriate legislative and procedural regulation.

\section{Conclusion}

The study conducted in this article allows us to draw the following conclusions. Currently, the imperfection of administrative justice in Ukraine creates obstacles to solving problems in criminal proceedings, in particular because of:

1) the problem in determining the subject matter jurisdiction, which is associated with incorrect classification of offenses and the difficulties in distinguishing administrative offenses from other illegal acts;

2) the problem of implementing the principle of efficiency of administrative proceedings, which in practice is expressed in violation of procedural deadlines, accompanied by the closure of cases in connection with the expiry of the administrative penalty;

3) closure of a criminal case (if the administrative offense acquires the characteristics of a criminal offense or crime) due to the expiration of the statute of limitations.

Therefore, we believe that the prospect of further reforming the system of administrative justice in order to avoid these conflicts should be:

settlement of administrative and criminal law through harmonization of the Criminal Code and the Code of Administrative Offenses and clear textual wording of the articles of codified acts, which would clearly separate administrative and criminal offences and avoid problems with determining subject matter jurisdiction; improving the organizational support of the administrative courts, in particular, the formation of an effective system of judicial administration, which will facilitate the rapid consideration of cases of administrative violations.

The implementation of these tasks in conjunction will help to solve the third of the problems referred to in the article, as well as minimize the deterrents to solve legal problems in criminal proceedings.

\section{References}

Aleksandrova, N. (2009). Fundamentals of administrative justice in Ukraine: a textbook for law faculties and law clinics. Kyiv: KNT. https://www.slideshare.net/CentrePravo/ss59878370

Banchuk, O. (2007). Administrative tort law: foreign experience and proposals for reform in Ukraine. Kyiv: Books for business. http://lib.rada.gov.ua/DocDescription?doc_id=1 41197

Bilous, I. (2020). On the features of closing a case because of the statute of limitations. Legal Internet resource "Protocol". https://protocol.ua/ua/pro_osoblivosti_zakrittya _spravi_cherez_zakinchennya_strokiv_davnosti /.

Brych, L. (2006). The problem of criteria for distinguishing offences from administrative offences in criminal law science. Bulletin of Lviv University, Series “Law”, Issue 43, pp. 255-272. Demskyi, E. (2008). Administrative procedural law of Ukraine: textbook. Kyiv: Yurinkom Inter. https://yurincom.com/files/content/Demsky__Admin-Proces-Pravo.pdf

Hood, L. (2018). Administrative justice can make countries fairer and more equal - if it is implemented properly. Theconversation. https://theconversation.com/administrativejustice-can-make-countries-fairer-and-moreequal-if-it-is-implemented-properly-108238 Khavroniuk, M. (2015). Notes on the reform of public law offenses. Bulletin of Criminal Procedure, Num. 1, pp. 250-256. http://nbuv.gov.ua/UJRN/vkc_2015_1_33

Lahutina, I., Osadchyi, A., Zakalenko, O., Kozachuk, D., \& Bolshakova, O. (2019). The modern concept of Ukrainian administrative justice. Amazonia Investiga, 8(23), 707-712. Retrieved

from https://amazoniainvestiga.info/index.php/amazo nia/article/view/925

Law No. 2341-III-2001. Official Gazette of the Verkhovna Rada of Ukraine, Kyiv, Ukraine, April 05, 2001. https://zakon.rada.gov.ua/laws/show/234114\#Text

Law No. 254k/96-VR-1996. Official Gazette of the Verkhovna Rada of Ukraine, Kyiv, Ukraine, 
June 28, 1996. https://zakon.rada.gov.ua/laws/show/254\%D0\% BA/96-\%D0\%B2\%D1\%80\#Text

Law No. 2747-IV-2005. Official Gazette of the Verkhovna Rada of Ukraine, Kyiv, Ukraine, July 06 ,

2005.

https://zakon.rada.gov.ua/laws/show/2747-

15\#Text

Law No. 80731-X-VR-1984. Official Gazette of the Verkhovna Rada of Ukraine, Kyiv, Ukraine, December 07 , 1984.

https://zakon.rada.gov.ua/laws/show/80731-

10\#Text

Monell, J. (2016). Administrative Justice. In: Farazmand, Ali (Ed.), Global Encyclopedia of Public Administration, Public Policy, and Governance (pp.1-5). USA: Springer International Publishing. 10.1007/978-3-31931816-5_950-1.

https://www.researchgate.net/publication/30456 8428_Administrative_Justice

Parker, C. (1991). The "Administrative Justice" provision of the constitution of the Republic of Namibia: A constitutional protection of judicial review and tribunal adjudication under administrative law. The Comparative and International Law Journal of Southern Africa, 24(1), 88-104. Retrieved May 6, 2021, from http://www.jstor.org/stable/23248813

Pypiak, M. (2016) Administrative court in the system of State bodies of Ukraine. (PhD
Dissertation). Lviv Polytechnic National University, Ukraine.

Russell-Einhorn, M. and Chlebny, J. (2006). Assessment of the Administrative Justice System in Macedonia. MK-Administrative Justice Report Review of October 03, 2006. https://www.legislationline.org/download/id/34 46/file/fYROM-

Administrative\%20Justice\%20Report\%20rev\% 203-10-06.pdf

Shcherbaniuk, O. (2013). The role of justice in ensuring the balance of private and public interests. Scientific Bulletin of Chernivtsi University, Series "Jurisprudence", Issue 714, pp. 65-69.

Smokevych, M. (2009). Determination of jurisdiction of administrative courts and the delimitation of judicial jurisdiction. Kyiv: Yurinkom Inter. http://www.vasu.gov.ua/userfiles/file/NKR/Mon ografii_Smokovich/Smokovich_2012_jurisdikci ja_adminsudiv.pdf

Svida, O. (2008). Administrative law-courts in Ukraine: formation and development. (PhD Dissertation). Odesa Law Academy, Ukraine. Vynokurova, I. (2011). Organizational and legal principles of administrative courts. (PhD Dissertation). National Academy of the Prosecutor's Office of Ukraine. 